\title{
FEATURES OF THE PHYSICOCHEMICAL PROPERTIES OF NARROW FRACTIONS OF AGGREGATES OF DIAMOND NANOPOWDERS MODIFIED WITH IRON IONS
}

\author{
H.D. Ilnytska, O.B. Loginova, V.V. Smokvyna, I.M. Zaitseva, O.V. Dovha \\ V. Bakul Institute for Superhard Materials of the National Academy of Sciences of Ukraine, \\ 2, Avtozavodska str., Kyiv,04074,Ukraine,e-mail:izaitseva@ukr.net
}

The paper presents the results of a study of the physical and chemical properties of narrow fractions of diamond nanopowders with a low content of non-diamond carbon grade ASUD-99. Six fractions with different average diameters of diamond particle aggregates from 28.785 to $3.891 \mu \mathrm{m}$ were obtained by separating a $0.2 \%$ aqueous suspension of the initial powders by the sedimentation method. It has been found that the smallest aggregates consist of larger particles with a smaller specific surface area and a lower interaction energy between them. This conclusion is confirmed by a decrease in the porosity of the obtained aggregates. So, if the pore volume in the largest aggregates of diamond particles is $0.859 \mathrm{ml} / \mathrm{g}$, then in the smallest $0.550 \mathrm{ml} / \mathrm{g}$, while the pore radius of diamond aggregates in different fractions changes insignificantly.

Separation in a magnetic field at different currents of diamond nanopowders with a specific magnetic susceptibility of $0.52 \times 10^{-8} \mathrm{~m}^{3} \mathrm{~kg}$, treated with a solution of $5 \%$ iron chloride, made it possible to obtain five fractions that differ from each other in specific magnetic susceptibility $(\chi)$ - from magnetic fractions with $\chi=4.30 \times 10^{-8} \mathrm{~m}^{3} / \mathrm{kg}$ to diamagnetic - with $\chi=$ $-0.11 \times 10^{-8} \mathrm{~m}^{3} / \mathrm{kg}$. It is shown that the modification of diamond nanopowders with iron ions increases the separation selectivity and makes it possible to isolate diamagnetic powders.

Keywords: diamond nanopowders, separation by sedimentation method and in a magnetic field, aggregates, specific surface area, specific magnetic susceptibility.

\section{Introduction}

Scientific progress stimulates the intensive development of all new nanomaterials with the aim of their implementation in technical fields directly related to biology, medicine, and environmental ecology. Among nanomaterials, carbon nanotubes and diamond powders of static and detonation synthesis are of particular interest. A significant surge in research in the field of nanomaterials science is due to the fact that this problematic revealed a number of gaps not only in understanding the nature of the features of materials in the nanostate, but also in its technological implementation.

As is known, diamond is a monovalent form of a polycarbonic substance formed by carbon atoms in the state of $s p^{3}$-hybridization, with a molecular structure in the form of a threedimensional network [1]. On going from diamond single crystals to detonation synthesis nanopowders, the sizes of carbon macromolecules can take values from several centimeters or millimeters to several angstroms [2]. The small size of the particles of diamond nanopowders determines their large specific surface area, which leads to an increase in the free surface energy of the system, as a result of which spontaneous aggregation of particles occurs.

Currently manufactured nanodispersed diamond powders have a wide range of cluster sizes: from 4 to $100 \mathrm{~nm}$. Such powders are widely used for the manufacture of polishing suspensions, pastes, adsorbents, catalysts for the oxidation of carbon monoxide, electrodes for chemical current generators, carriers of drugs [3-6]. When creating such nanomaterials and 
products from them, the same grain size and the same composition of the functional coating of their surface are of great importance. Thus, the use of carbon nanomaterials as carriers of drugs requires the development of methods for modifying their surface. A significant obstacle in the creation of suspensions and pastes based on nanodispersed diamond powders is their high tendency to aggregation.

In the last ten years, the Institute of Superhard Materials of the National Academy of Sciences of Ukraine has been carrying out research to study the physicochemical and surface properties of submicron and nanodispersed diamond powders of static and detonation synthesis. It has been established that their physicochemical properties are related to the chemical composition of the surface and the nature of their functional groups [7-10]. In this regard, the development of methods for increasing the selectivity of the separation of nanodispersed diamond powders of static and detonation synthesis and the isolation of diamagnetic fractions are of scientific interest.

\section{Research materials and methods}

The studies were carried out on nanodispersed powders of detonation synthesis diamond (SND powder) of the ASUD-99 grade with a low content of non-diamond carbon produced by the company "ALIT", obtained by gas-phase catalytic deposition of hydrocarbons on a nickelmagnesium catalyst [11]. In the initial powders, the total content of impurities and inclusions in the form of an non-combustible residue was determined from the difference in the masses of the studied powder before and after combustion at a temperature of $(900 \pm 10){ }^{\circ} \mathrm{C}$.

To obtain diamond nanopowders of the same size, the process of separating SND powder into fractions according to the size of diamond particle aggregates was carried out. The separation process was carried out by the methods of dynamic sedimentation in centrifuges with additives of surfactants. Centrifugation was carried out at a rotation speed of 900 to $3000 \mathrm{rpm}$. Separation of $0.2 \%$ aqueous suspension of diamond powders by sedimentation method made it possible to obtain six fractions of different particle size distribution.

To obtain magnetic and nonmagnetic fractions, further separation of the isolated fractions of diamond nanopowders in the form of a $0.2 \%$ aqueous suspension was carried out in a magnetic field at a current of $1 \mathrm{~A}$. To increase the selectivity of the process, iron ions were applied by adsorption from the solution to the surface of the powders. For application, a $5 \%$ solution of ferric chloride was used, the optimal concentration of which was established experimentally. The separation was carried out on an electromagnetic installation using metal balls with a diameter of 5 and $10 \mathrm{~mm}$ at a current from $0.1 \mathrm{~A}$ to $1.5 \mathrm{~A}$ and a corresponding magnetic field strength from 1 to $20 \mathrm{kA} / \mathrm{m}$. After separation, diamond nanopowders of magnetic and non-magnetic fractions were subjected to chemical treatment in hydrochloric acid to remove iron ions. After chemical treatment, all fractions were thoroughly washed to neutral waters and dried. According to the method developed at the Institute of Superhard Materials of the National Academy of Sciences of Ukraine [12], before and after chemical cleaning, the specific magnetic susceptibility $(\chi)$ was measured in them.

The estimation of the average size of aggregates of diamond particles and their size distribution was carried out on the basis of data obtained using a laser microanalyzer of grain size LMS-30 («Seishin», Japan). Physicochemical studies of the powder surface were carried out by nitrogen adsorption at low temperatures by the BET method. The degree of hydrophilicity was estimated from the change in the value of the free energy of saturation of the surface of the powders with water vapor [13].

\section{Results of studies}

Separation of an aqueous suspension of initial SND powder containing aggregates with an average size of $12.525 \mu \mathrm{m}$ by the sedimentation method made it possible to obtain six 
fractions of different particle size distribution, which differed in the average aggregate size from 28.785 to $3.891 \mu \mathrm{m}$. The separation results are shown in Table 1.

Figure 1 shows the results of the size distribution of the initial powder and two extreme fractions, isolated by centrifugation, with an average aggregate size of $28.785 \mu \mathrm{m}$ and $3.891 \mu \mathrm{m}$. As follows from Figure 1, two maxima are observed on the histogram of the initial powder, which indicates its inhomogeneity. The first maximum corresponds to the aggregate size of 4 $\mu \mathrm{m}$, and the second $-30-40 \mu \mathrm{m}$. On the histogram of powders with an average aggregate size $\mathrm{d}$ $=28.785 \mu \mathrm{m}$, a maximum is observed in the range from 10 to $100 \mu \mathrm{m}$. Moreover, the content of such particles is at the level of $70 \%$. For powders with an average aggregate size $d=3.891 \mu \mathrm{m}$, a maximum is observed in the range from 1 to $10 \mu \mathrm{m}$, and the content of such particles is $75 \%$. Thus, separation by the sedimentation method allows one to obtain more uniform powders in terms of the size of diamond particle aggregates.

Table 1. Results of separation of SND powder

\begin{tabular}{|c|c|c|c|c|}
\hline \multirow{2}{*}{ Fraction } & \multicolumn{2}{|c|}{ Fraction mass } & \multicolumn{2}{c|}{ Characteristics of fractions } \\
\cline { 2 - 5 } & carat & $\%$ & average aggregate size, $\mu \mathrm{m}$ & aggregate content, $\%$ \\
\hline 1 & 10.23 & 29.8 & 28.785 & 70 \\
\hline 2 & 18.82 & 54.84 & 22.533 & 78 \\
\hline 3 & 2.92 & 8.51 & 11.280 & 81 \\
\hline 4 & 1.37 & 3.99 & 7.932 & 59 \\
\hline 5 & 0.22 & 0.64 & 7.278 & 64 \\
\hline 6 & 0.76 & 2.22 & 3.891 & 75 \\
\hline the initial & 34.32 & 100.00 & 12.525 & \\
\hline
\end{tabular}

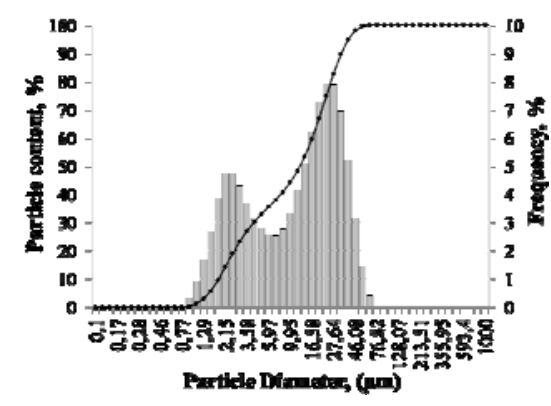

a

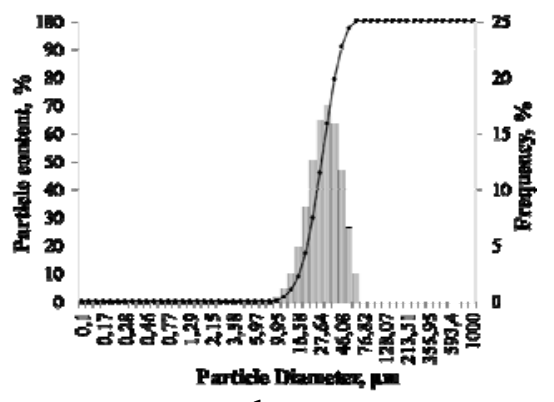

$\mathrm{b}$

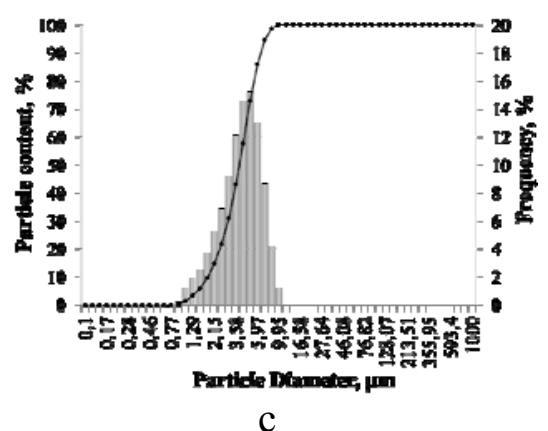

c

Fig. 1. Size distribution of SND powder aggregates of different fractions:

$\mathrm{a}$ - the initial with $\mathrm{d}=12.525 \mu \mathrm{m}, \mathrm{b}$ - fraction with $\mathrm{d}=28.785 \mu \mathrm{m}$,

$\mathrm{c}-$ fraction with $\mathrm{d}=3.891 \mu \mathrm{m}$

Physicochemical characteristics of the initial diamond powder and the isolated fractions No. 1, 3 and 6 (see Table 1) are presented in Table 2. It follows from Table 2 that the specific surface area of the studied diamond powders is different. If for the initial diamond powder the specific surface area was $177.5 \mathrm{~m}^{2} / \mathrm{g}$, for the fraction with the largest aggregate size it increased to $187.3 \mathrm{~m}^{2} / \mathrm{g}$, and for the fraction with the smallest agglomerate size it was $120 \mathrm{~m}^{2} / \mathrm{g}$. In accordance with Figure 1, the smallest aggregates consist of larger diamond particles with a lower interaction energy between them (Table 2). This conclusion is confirmed by a decrease in the porosity of the aggregates. If the pore volume in the largest aggregates of diamond particles is $0.859 \mathrm{ml} / \mathrm{g}$, then in the smallest ones it is $0.550 \mathrm{ml} / \mathrm{g}$, while the pore radius of aggregates of diamond particles in different fractions changes insignificantly. In Figure 3, the specific surface area and pore volume are compared for diamond particles of uniform size in fractions 1, 3, and 6. 
Thus, the sedimentation method presents the possibility of separating the initial SND powder into fractions with narrow ranges of particle sizes with different physicochemical characteristics.

Table 2. Physicochemical characteristics of diamond powder different fractions

\begin{tabular}{|c|c|c|c|c|c|}
\hline Fraction & $\begin{array}{c}\text { Specific surface } \\
\text { area, } \mathrm{m}^{2} / \mathrm{g}\end{array}$ & $\begin{array}{c}\text { Pore } \\
\text { volume, } \\
\mathrm{ml} / \mathrm{g}\end{array}$ & $\begin{array}{c}\text { Pore } \\
\text { radius, } \\
\AA\end{array}$ & $\begin{array}{c}\text { Adsorption } \\
\text { energy, } \mathrm{kJ} / \mathrm{mol}\end{array}$ & $\begin{array}{c}\text { Average } \\
\text { aggregate size, } \\
\mu \mathrm{m}\end{array}$ \\
\hline 1 & 187.3 & 0.858 & 91.6 & 12.275 & 22.533 \\
\hline 3 & 142.5 & 0.682 & 95.7 & 11.780 & 7.932 \\
\hline 6 & 120.0 & 0.550 & 94.7 & 7.864 & 3.891 \\
\hline the initial & 177.5 & 0.813 & 93.3 & 11.633 & 12.525 \\
\hline
\end{tabular}

The results of separation of the initial diamond powders in a magnetic field are presented in Table 3. As follows from Table 3, the diamond powders, separated into magnetic and nonmagnetic fractions, differ in the magnitude of the specific magnetic susceptibility and particle sizes. The non-magnetic fraction contains powders with $\chi=0.31 \times 10^{-8}, \mathrm{~m}^{3} / \mathrm{kg}$, the powders of the magnetic fraction have an an average diamond particle aggregate size 5.378, and in the nonmagnetic fraction $-13.209 \mu \mathrm{m}$.

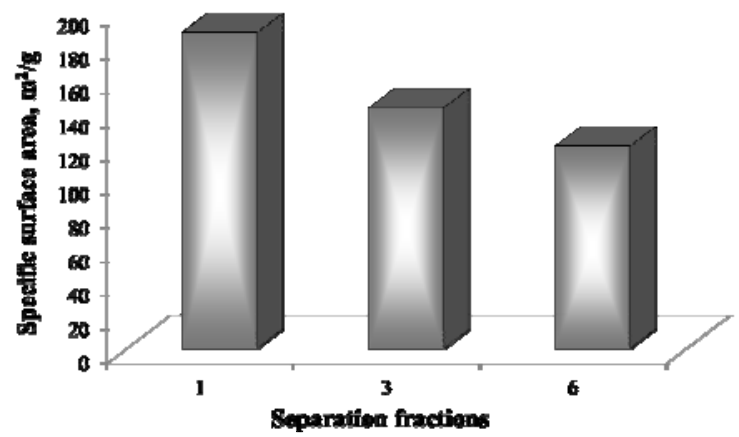

$\mathrm{a}$

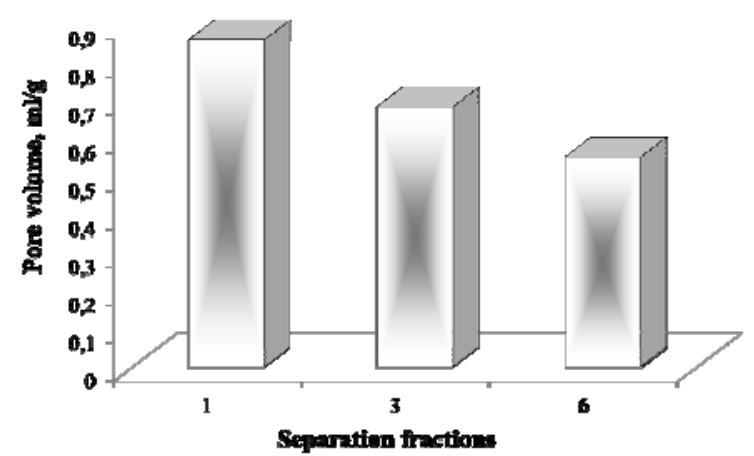

$\mathrm{b}$

Fig. 2. Specific surface area (a) and pore volume (b) different fractions (No. 1, 3 and 6) of homogeneous diamond particles

Table 3. Results of separation of initial diamond powder in a magnetic field

\begin{tabular}{|l|c|c|}
\hline \multicolumn{1}{|c|}{ Fraction } & Average aggregate size, $\mu \mathrm{m}$ & $\begin{array}{c}\text { Specific magnetic susceptibility, } \\
\chi \times 10^{-8}, \mathrm{~m}^{3} / \mathrm{kg}\end{array}$ \\
\hline magnetic & 5.378 & 1.0 \\
\hline non-magnetic & 13.209 & 0.31 \\
\hline the initial & 12.000 & 0.52 \\
\hline
\end{tabular}

The results of separation in a magnetic field of the initial diamond powders treated with iron chloride before and after chemical cleaning are presented in Table 4. As can be seen from Table 4 , both before and after chemical cleaning, the powders of both fractions differ in value $\chi$. So, before chemical cleaning for the magnetic fraction, it was $7.31 \times 10^{-8} \mathrm{~m}^{3} / \mathrm{kg}$, and for the nonmagnetic fraction $-3.27 \times 10^{-8} \mathrm{~m}^{3} / \mathrm{kg}$. After chemical purification, $\chi$ was $4.24 \times 10^{-8} \mathrm{~m}^{3} / \mathrm{kg}$ for the magnetic fraction, and $-0.31 \times 10^{-8} \mathrm{~m}^{3} / \mathrm{kg}$ for the non-magnetic fraction. Thus, the treatment of diamond particles with a solution of ferric chloride makes it possible to obtain diamagnetic powders from powders of the nonmagnetic fraction. 
Table 4. Results of separation of diamond powder treated with iron chloride

\begin{tabular}{|l|c|c|c|c|}
\hline \multirow{2}{*}{ Fraction } & \multicolumn{2}{|c|}{ Average aggregate size, $\mu \mathrm{m}$} & \multicolumn{2}{c|}{$\begin{array}{r}\text { Specific magnetic susceptibility, } \\
\chi \times 10^{-8}, \mathrm{~m}^{3} / \mathrm{kg}\end{array}$} \\
\cline { 2 - 5 } & $\begin{array}{c}\text { before chemical } \\
\text { treatment }\end{array}$ & $\begin{array}{c}\text { after chemical } \\
\text { treatment }\end{array}$ & $\begin{array}{c}\text { before chemical } \\
\text { treatment }\end{array}$ & $\begin{array}{c}\text { after chemical } \\
\text { treatment }\end{array}$ \\
\hline magnetic & 2.833 & 10.625 & 7.31 & 4.24 \\
\hline $\begin{array}{l}\text { non- } \\
\text { magnetic }\end{array}$ & 5.808 & 9.414 & 3.27 & -0.31 \\
\hline
\end{tabular}

Further separation of magnetic diamond powders treated with a 5\% solution of ferric chloride was carried out at a current from $0.1 \mathrm{~A}$ to $1.5 \mathrm{~A}$, and a corresponding magnetic field from 1 to $20 \mathrm{kA} / \mathrm{m}$. The results of the separation of diamond powders in magnetic fields of different strengths are presented in Table 5. As can be seen from Table 5, the initial diamond powders with a specific magnetic susceptibility of $0.52 \times 10^{-8} \mathrm{~m}^{3} / \mathrm{kg}$ were divided into five fractions, differing in value $\chi$ from $30 \times 10^{-8}$ to $-0.11 \times 10^{-8} \mathrm{~m}^{3} / \mathrm{kg}$. In this case, the average size of the agglomerates of diamond particles after chemical cleaning ranged from 18.931 to $13.868 \mu \mathrm{m}$.

Table 5. Results of separation of diamond powders in magnetic fields of different strengths

\begin{tabular}{|c|c|c|c|c|c|}
\hline \multirow{2}{*}{$\begin{array}{c}\text { Tension, } \\
\mathrm{kA} / \mathrm{m}\end{array}$} & \multirow[t]{2}{*}{ Fraction } & \multicolumn{2}{|c|}{ Fraction mass } & \multirow{2}{*}{$\begin{array}{c}\text { Average } \\
\text { aggregate size, } \\
\mu \mathrm{m}\end{array}$} & \multirow{2}{*}{$\begin{array}{c}\text { Specific magnetic } \\
\text { susceptibility, } \chi \times 10^{-8}, \\
\mathrm{~m}^{3} / \mathrm{kg}\end{array}$} \\
\hline & & carat & $\%$ & & \\
\hline 1 & magnetic 1 & 3.5 & 7 & \multirow[b]{2}{*}{18.931} & 4.30 \\
\hline 5 & magnetic 2 & 7.5 & 15 & & 3.81 \\
\hline 10 & magnetic 3 & 6.0 & 12 & 15.939 & 1.62 \\
\hline 15 & magnetic 4 & 10.5 & 21 & 14.547 & 0 \\
\hline \multirow[t]{2}{*}{20} & non-magnetic & 22.5 & 45 & 13.868 & -0.11 \\
\hline & the initial & 50.0 & 100 & 15.185 & 0.52 \\
\hline
\end{tabular}

Figure 3 shows the dependence of the specific magnetic susceptibility of diamond powders of the obtained fractions and the average size of aggregates of diamond particles on the magnetic field strength. As follows from Fig. 3, with an increase in the magnetic field strength, aggregates of diamond particles of smaller size with a lower value of $\chi$ are precipitated. At a magnetic field strength $20 \mathrm{kA} / \mathrm{m}$, diamagnetic powders with $\chi=-0.11 \times 10^{-8} \mathrm{~m}^{3} / \mathrm{kg}$ are released.

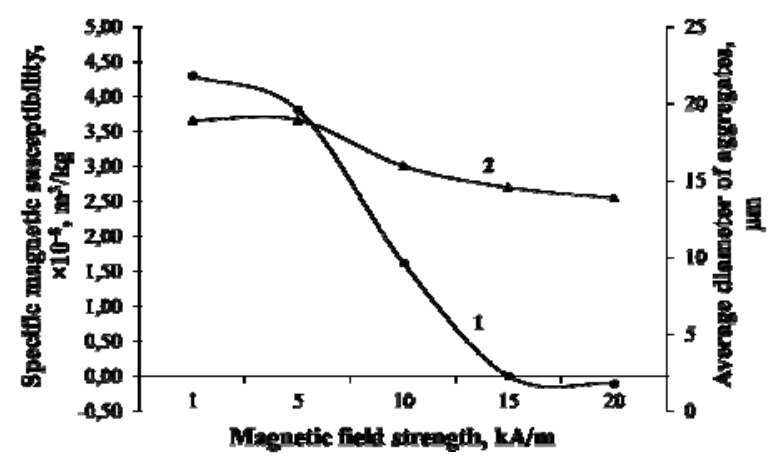

Fig. 3. Dependence of the specific magnetic susceptibility (1) and the average size of aggregates of diamond particles (2) on the magnetic field strength

After the separation of diamond powders in a magnetic field of different strengths, physicochemical characteristics were obtained for diamonds of the following fractions: magnetic 1 , magnetic 3, non-magnetic, and initial. The results of the determinations are presented in Table 
6. As follows from Tables 5 and 6 , with an increase in the specific magnetic susceptibility of diamond nanopowders, the average size of aggregates of diamond particles increases and their physicochemical characteristics increase.

Table 6. Physicochemical characteristics of diamond powders after separation in a magnetic field

\begin{tabular}{|l|c|c|c|c|}
\hline \multirow{2}{*}{\multicolumn{1}{|c|}{ Characteristics of fractions }} & \multicolumn{4}{c|}{ Fraction } \\
\cline { 2 - 5 } & magnetic 1 & magnetic 3 & $\begin{array}{c}\text { non- } \\
\text { magnetic }\end{array}$ & $\begin{array}{c}\text { the } \\
\text { original }\end{array}$ \\
\hline Average aggregate size, $\mu \mathrm{m}$ & 18.931 & 15.939 & 13.868 & 14.956 \\
\hline Non-combustible residue, \% & 0.615 & 0.532 & 0.491 & 0.575 \\
\hline Specific surface area, $\mathrm{m}^{2} / \mathrm{g}$ & 224.7 & 189.2 & 164.6 & 171.6 \\
\hline Pore volume, $\mathrm{ml} / \mathrm{g}$ & 0.870 & 0.751 & 0.694 & 0.807 \\
\hline Pore radius, $\AA$ & 97.4 & 95.1 & 93.7 & 94.5 \\
\hline $\begin{array}{l}\text { Free energy of surface saturation with } \\
\text { water vapor, J/g-mol }\end{array}$ & 114.6 & 112.9 & 98.7 & 107.5 \\
\hline
\end{tabular}

\section{Conclusions}

Thus, as a result of the separation of detonation synthesis diamond powders of the ASUD-99 grade with a low content of non-diamond carbon into a number of fractions by the methods of dynamic precipitation in centrifuges, powders with a narrow range of aggregate sizes were obtained. It was found that small aggregates consist of larger diamond particles with a lower interaction energy between them, and larger ones - of small particles with a higher interaction energy.

Separation of powders in a magnetic field using metal balls in aqueous suspensions with an initial value of the specific magnetic susceptibility of $0.52 \times 10^{-8} \mathrm{~m}^{3} / \mathrm{kg}$ made it possible to obtain nanodispersed powders with different specific magnetic susceptibility from $0.52 \times 10^{-8}$ to $-0.11 \times 10^{-8} \mathrm{~m}^{3} / \mathrm{kg}$ and the average diameter of the aggregates of the particles of the extreme fractions, differing from each other by about $30 \%$. The modification of diamond nanopowders with iron ions made it possible to increase the separation selectivity and to isolate diamagnetic fractions.

\section{References}

1. Turcheniuk K., Mochalin V.N. Biomedical Applications of Nanodiamond (Review). Nanotechnology. 2017. 28(25): 252001-252027.

2. Rosenholm J.M., Vlasov I.I., Burikov S.A., Dolenko T.A., Shenderova O.A. Nanodiamond-Based Composite Structures for Biomedical Imaging and Drug Delivery (Review). J. Nanosci. Nanotechnol. 2015. 15(2): 959-971.

3. Schrand Amanda M., Ciftan Hens Suzanne A., Shenderova Olga A. Nanodiamond Particles: Properties and Perspectives for Bioapplications. Critical Reviews in Solid State and Material Sciences. 2009. 34(1): 18.

4. Krueger A. The structure and reactivity of nanoscale diamond. J. Mater. Chem. 2008. 18: 1485.

5. Swati Chauhan, Neha Jain, Upendra Nagaich. Nanodiamonds with powerful ability for drug delivery and biomedical applications: Recent updates on in vivo study and patents. Journal of Pharmaceutical Analysis. 2020. 10(1): 1-12.

6. Detonation nanodiamonds. Technology, structure, properties and applications / ed. A.Ya. Vul, O. A. Shenderova. (SPb.: FTI im. A.F. Ioffe, 2016). [in Russian].

7. Vorobev A.E., Vorobev K.A. Nanodiamonds. Monograph. - M.: Mir nauki, 2018. - 160 s. - Access mode: http://izd-mn.com/PDF/34MNNPM18.pdf, free. 
8. Bogatyreva G.P., Marinich M.A., Bazaliy G.A., Gvyazdovskaya V.L. Obtaining elite grades of diamond powders of submicro- and nano-range. In: Synthesis, sintering and properties of superhard materials. (Kyiv, 2005). P. 63. [in Russian].

9. Novikov N.V., Bogatyreva G.P. Nanodiamonds of static and detonation synthesis and prospects for their applications. J. Superhard materials. 2008. 30: 73. [in Russian].

10. Oleinik G.S., Bochechka A.A. On the mechanism of forming nanosized particles of diamond detonation synthesized from explosive decomposition products. J. Superhard materials. 2008. 30. 143. [in Russian].

11. State Standard of Ukraine. (DSTU 3292-95).

12. M88 Ukraine 90.256-2004. Method of determining the specific magnetic susceptibility of powders of superhard materials. (SHM). (Kyiv: ISM NANU, 2004). [in Russian].

13. Bogatyreva G.P., Marinich M.A., Bazaliy G.A. Influence of various methods of modifying diamond micro- and submicropowders on the energy state of their surface. In: Physicochemical bases of formation and modification of micro- and nanostructures: Int. scient. conf. (Kharkov: NFTC MON and NAS of Ukraine, 2008). P.299. [in Russian].

\title{
ОСОБЛИВОСТІ ФІЗИКО-ХІМІЧНИХ ВЛАСТИВОСТЕЙ ВУЗЬКИХ ФРАКЦІЙ АГРЕГАТІВ НАНОПОРОШКІВ АЛМАЗУ МОДИФІКОВАНИХ ІОНАМИ ЗАЛІЗА
}

\author{
Г.Д. Ільницька, О.Б. Логінова, В.В. Смоквина, І.М. Зайцева, О.В. Довга
}

Інститут надтвердих матеріалів ім. В.М. Бакуля Національної академії наук України, вул. Автозаводська, 2, Київ, 04074, Україна, е-таil:izaitseva@ukr.net

Мета роботи - розробка способу підвищення селективності розділення нанодисперсних порошків алмазу статичного $i$ детонаційного синтезу $i$ виділення діамагнітних фракиій.

Вихідні порошки алмазу детоначійного синтезу марки АСУД-99 з низьким вмістом неалмазного вуглецю поділяли на ряд фракиій методами динамічного осадження в центрифугах для отримання фракиій з вузьким діапазоном розмірів агрегатів. Оцінювали середній розмір агрегатів алмазних частинок, їх розподіл за розмірами та проводили фізико-хімічні дослідження поверхні порошків отриманих фракцій. Встановлено, щзо дрібні агрегати складаються з більших алмазних частинок з меншою енергією взаємодіі між ними, а більші - з дрібних частинок з більш високою енергією взаємодії.

Для отримання магнітних і немагнітних фракиій подальще розділення порошку алмазу у вигляді 0,2\% водної суспензї проводили в магнітному полі. Підвищити селективність розділення $і$ виділити діамагнітні фракиії дозволило модифікування нанопорошків алмазу іонами заліза (використовували $5 \%$ розчину хлориду заліза). Після розділення нанопорошки алмазу магнітної $і$ немагнітної фракцій піддавалися хімічній обробці в соляній кислоті для видалення іонів заліза, потім всі фракції ретельно промивалися до нейтральних вод і висушувалися. До і після хімічного очищення в них була виміряна питома магнітна сприйнятливість.

Розділення порошків в магнітному полі з застосуванням металевих куль у водних суспензіях з вихідним значенням питомої магнітної сприйнятливості $0,52 \times 10^{-8} \mathrm{M}^{3} / \kappa 2$ дозволило отримати нанодисперсні порошки 3 різною питомою магнітною 
сприйнятливістю від $0,52 \times 10^{-8}$ до $-0,11 \times 10^{-8} \mathrm{M}^{3} / \kappa 2 \quad i$ середнім діаметром агрегатів частинок крайніх фракиій, щэо відрізняються між собою приблизно на $30 \%$.

Ключові слова: нанопорошки алмазу, розділення седиментаційним методом $i$ в магнітному полі, агрегати, питома поверхня, питома магнітна сприйнятливість

\title{
ОСОБЕННОСТИ ФИЗИКО-ХИМИЧЕСКИХ СВОЙСТВ УЗКИХ ФРАКЦИЙ АГРЕГАТОВ НАНОПОРОШКОВ АЛМАЗА МОДИФИЦИРОВАННЫХ ИОНАМИ ЖЕЛЕЗА
}

\author{
Г.Д. Ильницкая, О.Б. Логинова, В.В. Смоквина, И.Н. Зайцева, Е.В. Довгая
}

Институт сверхтвердых материалов им. В.Н. Бакуля Наџиональной академии наук

Украины, ул. Автозаводская, 2, Киев, 04074, Украина, e-mail:izaitseva@ukr.net

Цель работы - разработка способа повышения селективности разделения нанодисперсных порошков алмаза статического и детоначионного синтеза и выделение диамагнитных фракиий.

Исходные порошки алмаза детоначионного синтеза марки АСУД-99 с низким содержанием неалмазного углерода разделяли на ряд фракций методами динамического осаждения в иентрифугах для получения фракций с узким диапазоном размеров агрегатов. Оиенивали средний размер агрегатов алмазных частии, их распределение по размерам и проводили физико-химические исследования поверхности порошков полученных фракций. Установлено, что мелкие агрегаты состоят из более крупных алмазных частии с меньмей энергией взаимодействия между ними, а более крупные - из мелких частии с более высокой энергией взаимодействия.

Для получения магнитных и немагнитных фракиий дальнейшее разделение порошка алмаза в виде 0,2\% водной суспензии проводили в магнитном поле. Повысить селективность разделения $u$ выделить диамагнитные фракции позволило модифищирование нанопорошков алмаза ионами железа (использовали 5 \% раствора хлорида железа). После разделения нанопорошки алмаза магнитной и немагнитной фракций подвергались химической обработке в соляной кислоте для удаления ионов железа, затем все фракции тщзательно промывались до нейтральных вод и высушивались. До и после химической очистки в них была измерена удельная магнитная восприимчивость.

Разделение порошков в магнитном поле с применением металлических шаров в водных суспензиях с исходным значением удельной магнитной восприимчивостью $0,52 \times 10^{-8} \mathrm{~m}^{3} / \kappa 2$ позволило получить нанодисперсные порошки с разной удельной магнитной восприимчивостью от $0,52 \times 10^{-8}$ до -0,11 $\times 10^{-8} \mathrm{M}^{3} / \kappa 2$ и средним диаметром агрегатов частии крайних фракиий, отличающихся между собой приблизительно на $30 \%$.

Ключевые слова: нанопорошки алмаза, разделение седиментащионным методом и в магнитном поле, агрегаты, удельная поверхность, удельная магнитная восприимчивость 